Published in Wiseman, A. and Davidson, P. (eds.) Cross-nationally Comparative, Evidence-based Educational Policymaking and Reform. International Perspectives on Education and Society, Vol. 35. Bingley, West Yorkshire: Emerald Publishing Limited, 2018.

ISBN 978-1-78743-768-5.

http://dx.doi.org/10.1108/S1479-367920180000035009

\title{
One Size for all? - Policy Advice of the World Bank and the OECD on QAE in Basic Education in Russia, Brazil and China
}

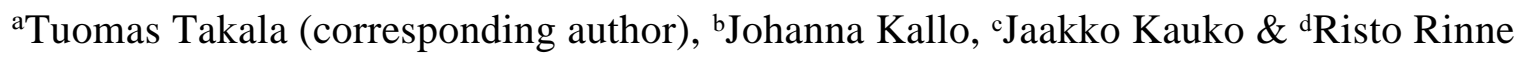

${ }^{a}$ Professor, School of Education, University of Tampere, 33014 Tampereen yliopisto, Finland, 35850 3951171,m.tuomas.takala@uta.fi

${ }^{b}$ Post-doctoral researcher, Department of Education, University of Turku, 20014 Turun yliopisto, Finland, 35823338827 johanna.kallo@utu.fi

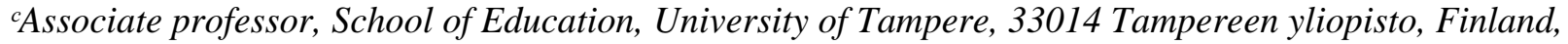
358503187788, jaakko.kauko@uta.fi

${ }^{d}$ Professor, Department of Education, University of Turku, 20014 Turun yliopisto, Finland, 35823338818 , risto.rinne@utu.fi

The analysis reported in this article is part of the project Transnational Dynamics in Quality Assurance and Evaluation Politics of Basic Education in Brazil, China and Russia', funded by the Academy of Finland [grant numbers 273871, 272874, 274218] and carried out in 2014-17. 



\title{
One Size for all? - Policy Advice of the World Bank and the OECD on QAE in Basic Education in Russia, Brazil and China
}

\begin{abstract}
The World Bank and the OECD play an important role in the dissemination of education policies. This article seeks to contribute to a nuanced understanding of how the two organisations formulate their policy advice, specifically concerning Quality Assurance and Evaluation in basic education, either in standardised form or takes into account local contexts. The case countries are Brazil, China and Russia, which in terms of their political power and economic resources differ from the typical World Bank client countries, but at the same time are not OECD members.
\end{abstract}

Key words: Policy advice, World Bank, OECD, Russia, Brazil, China

In the field of comparative education there is a vast and growing amount of research on how education policy agendas are formed at the transnational level and how these may influence policymaking in individual countries (e.g. Chabbott 2002; Mundy 2007; Steiner-Khamsi and Waldow 2012; Verger, Novelli and Altinyelken 2012). Much of this literature focuses on how international agencies attempt to influence national education policy decisions through framing policy discussions and related technical advice, and through prioritisations that signal the promise of external funding to projects and sector programs (e.g. Beech 2006; King 2004).

The increased role of knowledge and data management in the making of education policy has been analyzed as change in the mode of governance (Carvalho 2013; Fenwick, Mangez and Ozga 2014; Lawn and Segerholm 2011). As part of this change, policy advice has increasingly taken the form of conveying messages of 'international best practice'. An important role in the dissemination of policies is attributable to international organisations such as the World Bank and the Organisation for Economic Cooperation and Development (OECD). These can be characterised as 'epistemic communities', whose power pervades academia and society and diffuses through various networks of civil servants and consultants. Epistemic communities draw on knowledge dependency, created by increasing requirements for decision makers to deal with a broader range of issues in the expanding global economy and the consequent needs for external advice (Armingeon and Beyeler 2004; Haas 1992; Hasenclever, Mayer and Rittberger. 2002; Kallo 2009, 357).

However, there is disagreement among researchers on the extent to which the advice from international organisations either is given in standardised form or takes into account local contexts to explicitly allow 
adaptations and reformulations (e.g. Samoff 1999; Chabbott 2002, 162-8; Kauko and Diogo 2009; Waldow 2012; Kallo and Semchenko 2016). In this article, we take the first steps in systematically broadening such analysis on three countries - Brazil, China and Russia - which in terms of their political power and economic resources differ from the typical World Bank client countries, but at the same time are not OECD members. Our analysis seeks to contribute to a nuanced understanding of how the World Bank and the OECD have formulated their policy advice, specifically concerning Quality Assurance and Evaluation (QAE) in basic education, towards the intended beneficiaries of such advice. The actual influence that may follow from such attempts is beyond our scope, i.e. we are not assuming any necessary causality from policy advice to influence. The perspective is thus more narrow than that of the 'how globalisation affects education policy-making' literature (e.g. Dale 1999; Rizvi and Lingard 2010).

We define QAE broadly, covering the various means of governance related to the quality of education, including an operationalisation of quality by measurement. In the context of the World Bank and the OECD, and the national-level decision-making this especially relates to international and national large-scale assessments, but there are also other methods of QAE, ranging from school inspection to self-evaluation (see Kellaghan, Stufflebeam and Wingate 2003). In addition to the obvious goal of improving the quality of education, in whichever way it may be defined, is the building of a community with a shared understanding and policy of QAE: a function that is well-recognised in research focusing on Europe (Grek and Rinne 2010).

Our data consists of a set of World Bank and OECD publications from the three BCR countries, published during two decades from the mid-1990s onwards. The scope and formal status of these publications within the World Bank/ the OECD is variable: some are comprehensive reviews and others thematically more focused, some are prepared by large teams and in others authorship is acknowledged. The significant commonality is that all of them contain policy advice that is underpinned by the authority of the organisation. The document analysis is complemented by some factual information gained through interviews of relevant actors.

\section{The World Bank}

The World Bank is a global agenda setter in education policy that presents itself as a 'Knowledge Bank' and provides advice on what is termed 'international best practice' (Steiner-Khamsi 2012; Verger, Edwards and Altinyelken 2014). This agenda both defines what should be regarded as problems in the broader society and how these should to be tackled in education policy. It is available globally from the World Bank publications and websites, and it is also distributed through seminars, training and other events organised by the Bank (King 2002; World Bank 2011, 53). At the country level, the World Bank is a source of policy advice to borrower governments, which are formally in charge of their education policy decisions, but are also constrained by the prescriptions or even conditions attached to World Bank loans (Samoff 1999; Jones 2004). In this analysis, we focus on how the Bank formulates its policy advice to potential client governments.

A World Bank strategic document from 1995 states a straightforward technocratic position on policy advice in the education sector: 'Educational priorities should be set with reference to outcomes, using economic analysis, standard setting, and measurement of achievement through learning assessment'. (World Bank 1995a, 8) By contrast, in its Education Sector Strategy published in 1999, the Bank balances between the globally uniform and the context-specific perspective in the following terms: 'Given the great diversity in education 
across and within client countries, this strategy avoids prescriptive dictates ... However, there are some "topdown" priorities that emerge... from the consensus that there must be an unrelenting focus on the quality of teaching and learning'. (World Bank 1999a, 29) Then, in a 2005 strategic document, the more prescriptive tone comes to the fore: Countries need sound policies...To that end, Bank support for education will emphasize a sound knowledge base to inform all policy dialogue and other policy interventions.... used as much as possible as a lever for policy reform'. (World Bank 2005, 28) Finally, in its most recent Education Sector Strategy, the Bank is even more emphatically the 'Knowledge Bank': 'New tools for system assessment and benchmarking will provide detailed analysis of country capacities in a wide array of education policy domains...This information will allow policymakers and civil society organizations to make better-informed decisions about education reforms`. (World Bank 2011, 7)

The 'problematisation' and general policy advice on QAE in basic education found in the global WB documents during the past two decades can be summarised as follows:

1) The principal goal of education is seen as contributing to economic growth and poverty reduction.

2) This contribution is crucially dependent on the quality of education.

3) There is mounting evidence from international assessments that the quality of basic education is low in many countries.

4) Information on learning achievement is needed both for monitoring education quality as a basis for policy decisions, and for increased accountability of schools towards parents and communities, and towards donor agencies - such information would then provide incentives for improving quality.

5) The case is then made for establishment of national assessment systems and wider participation in international assessments, and related capacity building - to these the WB and other agencies should provide support (World Bank 1995a, 1-3, 9, 15; 1999a, iii, vii-ix; 2005, 12, 67-69; 2011, 6-8).

\section{Russia}

The fall of the Soviet Union as a political entity created a situation where external assistance to the transformation of the ex-Soviet countries into market economies and multi-party democracies became a legitimate domain of 'development assistance'. But it was less clear, what the possible legitimisation could be for provision of policy advice in the education sector. The Soviet Union had an education system that in some respects had functioned well and it had been a provider of educational assistance to developing countries, while inside the USSR Russia had been a model to the education systems of the other Soviet republics (Takala and Piattoeva 2012).

By the time of the breakup of the Soviet Union, the World Bank had attained a leadership role among the international development agencies in providing analyses and recommendations on educational policy to developing countries (King 1991; Heyneman 2003, 327-329). The post-Soviet situation posed a challenge to the Bank, to establish its hegemonic position also in the new discourse concerning educational assistance to the CIS countries. This challenge entailed testing the then prevailing policy prescriptions of the Bank against the perceived situation of the ex-Soviet countries (see World Bank 1995a, 137-144). 
In 1995, the World Bank published a comprehensive report, Russia - Education in the Transition (World Bank 1995b). Its analytical base was substantial, consisting of 33 background papers, of which nine were authored by experts in Russia. Apart from World Bank staff members, the team preparing the report brought together a wide range of international consultants. The financing of the consultancy work was put together through contributions from several sources and the multi-national composition of the team was expected to add to the perceived legitimacy of the team's report (Interview of former staff member of the World Bank).

The overall tone of the World Bank 1995 report is notable in that in the design of its early post-Soviet education reforms Russia had already been in congruence with the World Bank agenda. This is acknowledged in the following terms: 'These plans are all in the right direction and generally reflect where the priorities should be'. (World Bank, 1995b, p. xiii) Such a statement is clearly evidence of that the World Bank agenda resonated with the views of the reform-minded faction of Russian policy makers and education experts (cf. Johnson 1996, 40). In its deliberations on the potential role of future external assistance to education in Russia, the report acknowledges that No amount of assistance from outside Russia can possibly replace the domestic resources required for educational reform', but goes on to say that 'external assistance is of critical importance'. (World Bank 1995b, p. 69)

With respect to the quality of education and assessment of learning, the 1995 report notes the high performance of Russian students in international comparisons of achievement in science and mathematics, but contends that the system 'continues to teach skills inappropriate for the emerging market economy'. (World Bank 1995b, vi) It quotes a study in which Russian students scored relatively high in 'awareness of facts' - type of questions but lower in 'application of facts' and 'use of knowledge in an unanticipated circumstances', whereas in the market economy countries the difference between the two types of test scores was in the opposite direction (xi, 23-25). Subsequently, the World Bank reiterated this message in the reports Reforming Education in the Regions of Russia and Developing Skills for Innovative Growth in the Russian Federation. The key point in this problematisation is that, in order to increase productivity and innovativeness in the Russian economy, the education system must be reformed away from knowledge memorisation towards building higher-order cognitive skills (problem solving) and social interaction skills (World Bank 1999b, 8, 20-21; World Bank 2013, 8-12). In other words, in the above-mentioned reports the traditional Russian notion of the quality of education was fundamentally called into question.

In the three reports, QAE was then proposed as an important ingredient in the move towards better, or 'more modern', quality. The 1995 report recommended definition of uniform standards for educational outcomes and incorporating these into the examinations. Alongside the expected better quality of education, a standardised secondary school leaving examination would also serve to reduce inequality and corruption in the selection of students into higher education and standardised tests would provide information needed for international comparisons (World Bank 1995b, xv, 35, 42, 67). The prescription given in 1999 was for 'reformed testing, assessment and examinations' (World Bank 1999b, 20) and in 2013 that 'mechanisms for quality assessment and evaluation of educational services' and 'incentives for educational service providers to reward good performers's should be introduced (World Bank 2013, 57-62).

Apart from providing advice on QAE in the above-mentioned reports, the World Bank also financed a comprehensive Education Reform Project in Russia, implemented during 2002-2006. The description of the project background characterises the baseline situation as lacking 'an objective and fair system of assessing student outcomes'. As part of this project, a "quality assurance system', including 'performance indicators' were to be established both at the federal level and in three piloting regions (World Bank 2001a, 2-5).

\section{Brazil}


The history of Brazil during the $20^{\text {th }}$ century has seen both democratic and dictatorial regimes, and times of economic growth as well as stringency. However, during all these periods, Brazil has relied on co-operation with the World Bank. Judging by the number of projects in the education sector, the World Bank has been intensively and increasingly active in Brazil (Author, forthcoming). During 1987-2009 there were a total of 21 projects under the scheme now called 'Education for all', and starting from 2010 already 19 new projects have been introduced. The focus of the WB projects has shifted, as none of the 25 projects after 2003 have operated at the national level, while during 1987-2003 nine of the 15 projects were national (http://www.worldbank.org/projects/search?lang=en\&searchTerm=\&countrycode_exact=BR).

In post-dictatorial countries, such as Brazil after 1988, decentralisation has served as a counterweight for the bad experiences in history. This was also a practice recommended by the World Bank (Meade and Gershberg 2008). However, in a later stage, the Bank also advocated QAE mechanisms as a means to regain some of the central governance: 'In a decentralized education system such as Brazil's, ensuring that policy decisions made at the centre are operationalised in the classroom requires a set of vertical coherence-building, qualityassurance, and accountability mechanisms... standards, measurement, performance contracts' (World Bank 2001b, xiv).

After the national level projects had ceased, an aggregative World Bank report on education in Brazil, written by Bank staff members, was published only in 2012. The improvement of learning results, as evidenced by test results, is in this report attributed to the reforms started by the Cardoso government since the 1995 and continued during the Lula administration since 2002 (Bruns, Evans and Luque 2012, ix, xviii-ixx). These reforms include the means to equalise funding between schools by earmarking federal budget funds for state and municipal schools (FUNDEF), financial support to families (Bolsa Escola, Bolsa Familia) and the new means for education assessment: SAEB (System for Basic Education Assessment), a federal level assessment covering all schools, and IDEB (Index of Basic Education Development) which combines the SAEB scores with background data regarding schools and students (ixx, 7).

A change in tone since the early 2000s is the new type of comparison with other nations. The 2012 report is impressed by the improving performance of Brazilian students in the PISA tests, but notes that the level is still lagging behind the OECD countries in general and other middle-income countries (Bruns, Evans and Luque 2012, xvii, xx). The situation is problematised by suggesting that 'what counts for economic growth is what students actually learn' and here 'the crucial yardstick is ... the best performing education systems globally'. (16) PISA as such is evidently regarded as an unarguably valid benchmark for all countries, independent of context. In comparison with the East Asian countries a 'quality gap' is seen to result from factors such as the duration of school days, infrastructure, curriculum and pedagogy, and qualified teachers (xxvi-xxvii, 18). As the 2001 report, the 2012 report also suggests investment in the quality of education and QAE. The teachers' use of time in classrooms should be better evaluated and performance rewards should be implemented, both of which were already ongoing developments in Brazil (ix, 53-55, 65).

\section{China}

The Chinese education system has been shaped by the Chinese cultural and intellectual tradition, especially Confucianism. The principles of top-down centralised governance have stressed accountability and measurement by examinations. During the first decades of the People's Republic of China education was seen generally as an ideological, economic and political tool, and egalitarianism was the expected standard to aim for. The opening up of the Chinese economy and society to the outside world since 1978 implied for education enhanced cooperation and increased encounters with ideas that travel in education and society globally. Several 
international organisations including the World Bank became active in promoting transnational educational practices and programmes in China. (Author, forthcoming).

Cooperation between China and the World Bank was established in 1971 and reinstated in 1980, so unlike in Russia, the WB was already present in China before the transition towards a market economy. The WB has issued to China both soft loans through the International Development Association (IDA) and hard loans through the International Bank for Reconstructions and Development (IBRD) (Zhou, Zhang and Zhang 2015.) Given the country's rapid economic growth, after 1999 only IRBD loans have been made available for China. In addition to the loans, assistance from the World Bank has covered several other aspects such as technological assistance, policy consultations, and personnel training. The history of the educational cooperation between China and the World Bank can be divided into three phases: 1) the start-up and rapid development phase, with special focus on higher and vocational education (1980s), 2) the steady momentum phase, with increasing support from the Bank for the Chinese government in realising the universalisation of nine-year compulsory education as part of the Education for All process (1990s), and 3) the stage of gradual reduction of international assistance (2000s) (Zhao (2012).

The approach of the World Bank towards QAE is manifested in its publications that deal with basic education in China. The paper on Governance of Basic Education: Service Provision and Quality Assurance in China, authored by a Bank staff member (Wang 2004) indicates several problems of Chinese basic education. Those related to QAE include an overemphasis on high stakes examinations, increased gaps in quality between schools and inadequate monitoring and evaluation practices. The remedial measures are prescribed without reservation: 'developing indicators for education quality at national level' and "setting of national standards for modern teaching and learning' - i.e. different from the traditional Chinese notion of education quality, and on this basis 'establishment of outcome-based and student-oriented quality assurance mechanisms at all schools' (Wang (2004.). The same line of advice is given in Education Notes - EFA and Beyond: Service Provision and Quality Assurance in China (Wang, 2005). The document invokes the global trend that focuses on outcome-based education and states that there is a growing recognition that control of inputs such as resources, teachers, curriculum, school programmes, facilities and equipment are inadequate indicators for measuring outcomes'. This necessitates development of a national assessment system (Wang, 2005.)

\section{OECD}

The OECD has established itself in a key position in the production and dissemination of data on education systems, covering all levels of education. Compared with the World Bank, basic education has been a lesser priority for the OECD. Increasingly, however, the OECD has also become a prominent actor in the area of QAE in basic education through the international assessment programme PISA, which has created standardised data, ranking scales, indicators and benchmarks (Martens 2007, 49: Spring 2009, 62; Lawn and Grek 2012, 10-11, 69-70, 83-84; Sellar and Lingard 2016). The underlying ideology is to assimilate the educational practices of countries with diverse traditions and cultures to seemingly unassailable standards of technocratic rationality and economic competitiveness (Simola et al. 2013). Initially confined to the OECD member countries, the PISA programme has been gradually expanded also to non-member countries - including Brazil, China and Russia - which typically have a history of being clients of the World Bank. For such countries this represents a significant symbolic upgrading of their international status. Their participation is based on expressions of interest from the countries that are then vetted by the OECD secretariat against the requirements for technical expertise and funding (www.oecd/org/pisa/pisafaq). 
The vision of the World Bank as a knowledge bank mentioned earlier resembles the operational portfolio of the OECD, which provides various types of knowledge services to its constituencies. The most prominent of these are the OECD country reviews of education policies which are conducted at the highest level and have been undertaken also in a number of non-member countries. The review process consists of different phases. First, the Ministry of Education of the target country draws up a background report on the national education policy for a review team appointed by the OECD. Thereafter, the review team visits the country concerned and gathers information, steered by the OECD guidelines. Then the review team, together with the OECD Secretariat, prepares a country note on the basis of the information gathered. When the background reports and country notes have been completed, the OECD Secretariat produces for the OECD Education Policy Committee a final report, in which 'good practices' and policy recommendations are presented (Kallo, 2009; Rinne, Kallo and Hokka, 2004). This kind of a procedure is evidently designed so as to provide a conducive setting for dialogue between the review teams and the education policy makers and other experts of the country under review - in reality the amount and kind of dialogue will be influenced by the perceived power relationship between the two sides and their knowledge resources.

\section{Russia}

OECDs Review of National Policies for Education - the Russian Federation (OECD 1998) was prepared by a group of 27 experts from 16 countries. In the early sections of the report, strong praise is given to the professionalism of Russian educators and the achievements (proud heritage') of the system, and the recommendations that follow are described as 'grounded in concrete historical reality' and 'offered in the spirit of collegial support'. (9) That said, the report 'focuses on what remains to be done, rather than what has been accomplished'. (12)

In a later section, a critical analysis of the existing QAE practices in Russia is presented (OECD 1998, 89-95). Here the tone of the report is more prescriptive and in line with the above-mentioned recommendations presented in the World Bank 1995 report. For our analysis, notable formulations in the recommendations of the OECD team are that the definition of general achievement standards at the federal level and related development of tests should be 'based on international experience' and be 'in touch with international developments'. (91, 94-98, 109-110)

There is a contradiction in that, first, the OECD's report acknowledges that 'Russian personnel are concerned to preserve a holistic approach to student evaluation and to avoid an overly narrow mode of evaluation' (OECD 1998,91 ) and that the assessment system to be developed 'should retain the strong features of the Russian tradition, specifically the tight, immediate relationship between teaching and learning through school-based, often oral assessment which greatly esteems important rhetorical skills... and inter-personal skills not easily measured through written tests'. (99) The text then goes on to state that 'Classroom tests and oral questioning also concentrate on memorizing facts' which is the same problematisation than that presented in the World Bank report: such practices are not conducive to applying facts or using knowledge in unanticipated circumstances. In a market economy, these are the skills that count'. (100-1) If such skills were emphasised in revised content of examinations, this would lead to a change in what is actually taught and learned (102-3). Advice from the OECD team attempts to balance between these divergent perspectives by the following formulations: in order not to make 'reforms seen as the imposition of new and "foreign" approaches... the desired goals need to be grafted on to what has been positive in the curricular content and methodology of traditional Russian education' (16) and 'teacher confidence needs to be sustained so that in moving towards 
new practices, past work is not denigrated'. (22)

\section{Brazil}

In general, the OECD sees Brazil as its 'key partner', together with China, South Africa, India, and Indonesia. In this relationship 'Brazil has benefited from the OECD community's wealth of policy expertise and experience, and the global policy community has learnt from Brazil's perspectives' (OECD 2013a). More particularly, the progress of Brazil in education during 2000-2010 is an example of something a country can make by building on its participation in PISA to improve schooling outcomes' (OECD 2015, 7). As already pointed out in the section analysing the World Bank, the PISA results have become important tools for connecting Brazil to the global discussions of educational benchmarking.

In the education sector, the OECD has never conducted a county review of the whole Brazil, but only of the state of Santa Catarina (OECD 2010). This is also the focus of our analysis. The identification of problems by this OECD review is similar to that found in World Bank publications. Perhaps the most central concern of the Santa Catarina authorities regarding education is the poor level of performance of students as measured on national and international tests'. (346) In spite of the increasing financial inputs the test results have not risen accordingly, 'suggesting that service delivery is inefficient rather than under-funded'. (19) The consequent advice then is that, instead of focusing on inputs, the State Secretariat for Education should be directing its attention to improving learning (161).

While learning outcomes in Santa Catarina are better than in other Brazilian states, they are disappointing in comparison with other countries 'given the state's favourable socio-economic conditions and high investments in education'. (OECD 2010, 155) Teacher quality in Brazil is described as uneven, with problems arising from the large number of temporary teachers, instability of the career, absenteeism, and the insufficient quality of teacher training $(23,64,144,225,235,250)$. The pedagogical advice from the OECD review emphasises more interaction in the classroom $(22,345)$, and 'continuous in-class evaluation and constructive feedback' that should replace the state policy of automatic promotion (136). Regarding teachers, the review supports 'innovative teacher bonus rewards' and a teacher assessment system $(64,247)$.

The OECD review sees many difficulties in the decentralised governance of Santa Catarina. The federal, state and municipal, and public and private schools create different administrative structures between which there is little coordination (OECD 2010, 20, 71-74). The review suggests harmonising management in the state by creating 'state-based regulatory mechanisms for co-ordination and operational oversight' and strengthening local coordination $(81,342)$.

\section{China}

China joined the OECD as an observer country in 1996 and, like Brazil, has thereafter been elevated to one the 'key partners' of the organisation. The collaboration between China and the OECD has yielded several reviews of Chinese higher and vocational education, but none of basic education. However, the latter is dealt with in reports of Shanghai's success in OECD's PISA programme rounds of 2009 and 2012. China's motivation to participate in PISA has emanated from national and supranational reasons. At the national level there was an endeavour to evaluate the ongoing national reform efforts (Akbik, Martens and Zhang, 2014), and the World Bank had recommended that China join the international student assessment tests (Dahlman, Zhihua Zeng and Wang 2007). 
The special in-depth reports on PISA (e.g. OECD 2013b) elaborate on the success of Shanghai in and thereby raised Shanghai as a reference society. These reports highlight several aspects of Shanghai's top performance and thereby encourage nations, such as the USA to 'look East', (Sellar and Lingard 2013; OECD 2013b). The OECD praises China/Shanghai for a number of reforms taken in the past years: developing a more inclusive education system in which all students are expected to perform at high levels, raising teacher pay and upgrading of teacher standards and teacher education, and giving more emphasis to the students' deep understanding and their abilities to solve new problems and think creatively. These lessons have been reflected in the reforms of curriculum and examinations, which have given way for more curricular choice for students, fostered students' engagement in learning and allowed more latitude for local authorities to decide the content of examinations (OECD , 2011.) But the same report also underlined the tension between the evolving concept of quality education and the heavy tradition of examinations: Examination pressure remains a major concern to educators, parents and policy makers.... There is a general belief that emphasis on examinations jeopardises the genuine development of young people... but few effective solutions have emerged to reduce or minimise examination pressures'. (89)

In the past years, China has developed a new assessment system, and for this the Chinese specialists have consulted among others the OECD (Interview of senior official at the Centre for National Assessment of Education Quality, China). New assessments are conducted every year, with the complete cycle taking three years as only two subjects are assessed each year. The first two subjects are mathematics and physical education, followed by Chinese literature and art, and then science and moral education. The content of the national assessment is quite different from the content of traditional examinations because it has much in common in terms of its formation and procedures with standardised testing, such as PISA (Author, submitted article)

\section{Conclusion}

The aim of our analysis has been to contribute to a nuanced understanding of how the World Bank and the OECD have formulated their policy advice, specifically concerning Quality Assurance and Evaluation in basic education, towards the intended beneficiaries of such advice. The basic question is, to which extent the advice from international organisations either is given in standardised form or takes into account local contexts to explicitly allow adaptations and reformulations .

Prescriptions given in the tone of 'international best practice' are predominant in the analyzed material. The core content of the advice from both the World Bank and the OECD to the three countries is that education policy decisions should be informed by data from a QAE system, complemented by the suggestion that teachers' remuneration should be linked to their differential performance in terms of learning outcomes. This position sees the quality of education as a concept that has a globally applicable definition. QAE is essentially a tool for participation in international comparison of learning achievement that provides valuable information about a country's potential in global economic competition. A tacit function in the advice is also the creation of a common epistemic community, using the standard language of QAE in its communication regardless of the context.

In the advice given to all our three case countries, the PISA tests are evidently regarded as providing an unarguably valid global benchmark. For countries that are not members of the OECD, and which have a history of being clients of the World Bank, participation in PISA as such represents a significant symbolic upgrading of their international status. At the same time, the international rankings of learning achievement also subject 
the countries to a broader international comparison. The World Bank reports on Russia contains a criticism of the traditional Russian notion of education quality that is seen as a hindrance to the transition into market economy, and then call for new kind of skills to be developed in the education system. Similarly, the World Bank report on Brazil first gives credit to the educational progress of the country, but then changes the perspective into the 'global learning Olympics', thereby sending the message hat for further improvement of learning outcomes - and consequent benefits for economic growth - Brazil should emulate the policies of the better-performing countries.

In the material analyzed for this article, the socio-cultural context in which pedagogy is embedded, is most explicitly acknowledged in the OECD review of the education system in Russia. The traditional Russian notion of the quality of education, prevalent among teachers, was on the one hand given praise, but was nevertheless fundamentally called into question. Similar to the advice from the World Bank, the OECD report recommended QAE as an important ingredient in the move towards better, or "more modern", quality, that would facilitate Russia's transition into market economy. It remains unclear to what extent such contradictory statements meant that different definitions of education quality were seen as acceptable or even desirable, or whether they were warnings against unrealistic expectations of the pace of change towards a postulated uniform goal.

Also in China the traditional notion of education quality, measured by the examinations, has been criticised in both the World Bank and the OECD publications. However, the recent success of Shanghai in the PISA tests indicates that at least in the schools participating in PISA, the quality of teaching and learning is in line with what is measured by these tests, and hence Shanghai qualifies as a model case - i.e. is transformed from a target to a source of advice. In the case of Brazil, both the World Bank and the OECD have offered advice on how QAE should be used to counteract the negative effects of decentralisation of the education system, thus retracting from the Bank's earlier advice to pursue decentralisation. 


\section{References}

Abkik, Alexander, Martens, Kerstin, and Chenjian Zhang. 2014. Joining the World of Education? China's Reaction to Internationalisation Pressures. In Internationalization of Education Policy - A New Constellation of Statehood in Education, edited by Martens, Kerstin, Knodel, Philipp, and Michael Windzio, 224-244. Palgrave: McMillan.

Armingeon, Klaus, and Michelle Beyeler, eds. 2004. The OECD and European Welfare States. Northhampton: Edward Elgar Publishing, Inc.

Beech, Jason. 2006. Redefining Educational Transfer: International Agencies and the (Re)production of Educational Ideas. In Identity, Education and Citizenship - Multiple Interrelations, edited by Sprogoe, Jonas, and Thyge Winter-Jensen. Frankfurt am Main: Peter Lang.

Bruns, Barbara, Evans, David, and Javier Luque. 2012. Achieving World-Class Education in Brazil: The Next Agenda. Washington, DC: World Bank.

Carvalho, Luis Miguel. 2013. The Fabrications and Travels of a Knowledge-Policy Instrument. European Educational Research Journal 11 (2): 172-188.

Chabbott, Colette. 2002. Constructing Education for Development - International Organizations and Education for All. New York: Routledge \& Falmer.

Dahlman, Carl, Zhihua Zeng, Douglas, and Shuilin Wang. 2007. Enhancing China's Competitiveness through Lifelong Learning. Washington D.C.: World Bank.

Dale, Robert. 1999. Specifying Globalization Effects on Education Policy: A Focus on the Mechanisms. Journal of Education Policy 14 (1): 1-17.

Fenwick, Tara, Mangez, Eric, and Jenny Ozga. 2014. Governing Knowledge: Comparison, KnowledgeBased Technologies and Expertise in the Regulation of Education. London: Routledge.

Grek, Sotiria, and Risto Rinne. 2011. Fabricating Europe: From Culture to Numbers. In Fabricating Quality in Education - Data and Governance in Europe, edited by Ozga, Jenny, Dahler-Larsen, Peter, Segerholm, Christina, and Hannu Simola, 19-31. London: Routledge,

Haas, Peter. 1992. Introduction: Epistemic Communities and International Policy Coordination. International Organisation 46(1): 1-35.

Hasenclever, Andreas, Mayer, Peter, and Volker Rittberger. 2002. Theories of International Regimes. Fifth Edition. Cambridge Studies in International Relations 55. Cambridge: Cambridge University Press,

Heyneman, Stephen. 2003. The History and Problems in the Making of Education Policy at the World Bank 1960-2000. International Journal of Educational Development 23 (3): 315-338.

Johnson, Mark S. 1996. Russian Education Reform in the 1990s. The Harriman Review 9 (45): 36-45.

Jones, Phillip W. 2004. Taking the Credit: Financing and Policy Linkages in the Education Portfolio of the World Bank. In The Global Politics of Educational Borrowing and Lending, edited by Steiner-Khamsi, Gita. New York: Teachers College Press. 
Kallo, Johanna. 2009. OECD Education Policy. A Comparative and Historical Study Focusing on the Thematic Reviews of Tertiary Education. FERA: Jyväskylä.

Kallo, Johanna, and Anzhelika Semchenko. 2016. Translation of the UNESCO/OECD Guidelines for Quality Provision in Cross-border Higher Education into Local Policy Contexts: A Comparative Study of Finland and Russia. Quality in Higher Education 22(1): 20-35.

Kauko, Jaakko, and Sara Diogo. 2010. Comparing Higher Education Reforms in Finland and Portugal: Different Contexts, Same Solutions? Higher Education Management and Policy, 23 (3): 115-133.

Kellaghan, Thomas, Stufflebeam David, and Lori Wingate L. 2003. Introduction. In International Handbook of Educational Evaluation, edited by Kellaghan Thomas, and David. Stufflebeam, 1-6. Dordrecht: Kluwer Academic Publishers.

King, Kenneth. 1991. Aid and Education in the Developing World - The Role of the Donor Agencies in Educational Analysis. Harlow: Longman.

King, Kenneth. 2002. Banking on Knowledge - The New Knowledge Projects of the World Bank. Compare 32 (3): 311-326.

King, Kenneth. 2004. The External Agenda of Educational Reform: A Challenge to Educational Self-

Reliance and Dependency in Sub-Saharan Africa. Journal of International Cooperation in Education, 7 (1): 85-96.

Lawn, Martin, and Christina Segerholm. 2011. Europe through Experts and Technologies. In Fabricating Quality in Education - Data and Governance in Europe, edited by Ozga, Jenny, Dahler-Larsen, Peter, Segerholm, Christina, and Hannu Simola, 32-46. London: Routledge.

Lawn, Martin, and Sotiria Grek. 2012. Europeanizing Education. Governing a New Policy Space. Oxford: Symposium Books.

Martens, Kerstin. 2007. How to Become an Influential Actor - The 'Comparative Turn' in OECD Education Policy. In New Arenas of Education Governance - The Impact of International Organizations and Markets on Educational Policy Making, edited by Martens, Kerstin, Rusconi, Alessandra, and Kathrin Leuze, 40-56. New York: Palgrave Macmillan.

Meade, Ben, and Alec Gershberg. 2008. Making Education Reform Work for the Poor: Accountability and Decentralization in Latin America. Journal of Education Policy 23(3): 299-322.

Mundy, Karen. 2007. Global Governance, Educational Change. Comparative Education 43 (3): 339-357.

OECD. 1998. Review of National Policies for Education - the Russian Federation. Paris: OECD.

OECD. 2010. Reviews of National Policies for Education: Santa Catarina State. Brazil. Paris: OECD.

OECD. 2011. Shanghai and Hong Kong: Two Distinct Examples of Education Reform in China. In Lessons from PISA for the United States. Paris: OECD. 
OECD. 2013a. Active with Brazil. Better Policies for Better Lives. Mexico \& Paris: OECD Centre for Latin America.

OECD 2013b. Strong Performers and Successful Reformers in Education. In Lessons from PISA 2012 for the United States. Paris: OECD.

OECD. 2015. Beyond the Millennium Development Goals: Towards an OECD Contribution to the post-2015 Agenda. https://www.oecd.org/dac/POST-2015\%20Overview\%20Paper.pdf.

Rinne, Risto, Kallo, Johanna, and S. Hokka. 2004. Too Eager to Comply? OECD Education Policies and the Finnish Response. European Educational Research Journal 3(2): 455-485.

Rizvi, Faisal, and Bob Lingard. 2010. Globalizing Education Policy. London: Taylor \& Francis.

Samoff, Joel. 1999. Education Sector Analysis in Africa: Limited National Control and Even Less National Ownership. International Journal of Educational Development, 19 (4-5 ): 249-272.

Sellar, Sam, and Bob Lingard. 2013. The OECD and the Expansion of PISA: New Global Modes of Governance in Education. British Educational Research Journal, 40 (6): 917-936.

Sellar, Sam, and Bob Lingard. 2016. The Changing Organizational and Global Significance of the OECD's Education Work. In Handbook of Global Education Policy, edited by Mundy, Karen, Green, Andy, Lingard, Bob, and Antoni Verger, 357-373. Oxford: Wiley-Blackwell.

Simola, Hannu, Rinne, Risto, Varjo, Janne and Jaakko Kauko. 2013. The Paradox of the Education Race: How to Win the Ranking Game by Sailing to Headwind. Journal of Education Policy 28 (5): 612-633.

Spring, Joel. 2009. Globalization of Education. An Introduction. London \& New York: Routledge.

Steiner-Khamsi, Gita. 2012. For All by All? -The World Bank's Global Framework for Education. In The World Bank and Education: Critiques and Alternatives, edited by Klees, Stephen, Samoff, Joel and Nelly Stromquist. Rotterdam: Sense Publishers.

Steiner-Khamsi, Gita, and Florian Waldow, eds. 2012. Policy Borrowing and Lending in Education London: Routledge.

Takala, Tuomas, and Nelli Piattoeva. 2012. Changing Conceptions of Development Assistance in the International Discourse on post-Soviet Countries. International Journal of Educational Development 32 (1): $3-10$.

Verger, Antoni \& Edwards, D. Brent Jr., and Hulya Altinyelken. 2014. Learning from All? The World Bank, Aid Agencies and the Construction of Hegemony in Education for Development. Comparative Education 50 (4): 381-399.

Verger, Antoni, Novelli, Mario and Hulya Altinyelken, eds. 2012. Global Education Policy and International Development.New York: Bloomsbury. 
Waldow, Florian. 2012. Standardisation and Legitimacy: Two Central Concepts in Research on Educational Borrowing and Lending. In Policy Borrowing and Lending in Education. edited by Steiner-Khamsi, Gita, and Florian Waldow, 411-427. London Routledge.

Wang, Y. 2004. Governance of Basic Education: Service Provision and Quality Assurance in China. Washington, DC: World Bank.

Wang, Y. 2005. EFA and Beyond: Service Provision and Quality Assurance in China. Education Notes. Washington, D.C.: World Bank.

World Bank. 1995a. Priorities and Strategies for Education - A World Bank Review. Washington, D.C.: World Bank

World Bank. 1995b. Russia - Education in the Transition. Washington, D.C: World Bank.

World Bank. 1999a. Education Sector Strategy. Washington, D.C.: World Bank.

World Bank. 1999b. Reforming Education in the Regions of Russia. Washington, D.C.: World Bank.

World Bank. 2001a. Russian Federation - Education Reform Project. Report No. PID7425.

World Bank. 2001b. Brazil - Teachers Development and Incentives: A Strategic Framework. Washington, D.C: World Bank.

World Bank. 2003. Next Steps for Education in Four Selected States in Brazil. Washington, DC: World Bank.World Bank.

World Bank. 2005. Education Sector Update. Washington, D.C.: World Bank.

World Bank. 2011. Learning for All 2020 - World Bank Group Education Strategy. Washington D.C.: World Bank.

World Bank. 2013. Developing Skills for Innovative Growth in the Russian Federation. Washington D.C.: World Bank.Zhao, Y. 2012. International Multilateral Education Aid Received by China. Chinese Education and Society 45 (1): 69-76.

Zhou, H., Zhang, J., and M. Zhang. 2015. Foreign Aid in China. Dordrecht: Springer. 